\title{
The aac A-aphD Gentamicin and Kanamycin Resistance Determinant of Tn4001 from Staphylococcus aureus: Expression and Nucleotide Sequence Analysis
}

\author{
By DUNCAN A. ROUCH, MARY E. BYRNE, YEUN C. KONG†AND \\ RONALD A. SKURRAY* \\ Department of Microbiology, Monash University, Clayton, Victoria 3168, Australia
}

(Received 27 March 1987; revised 7 July 1987)

\begin{abstract}
The aac A-aphD aminoglycoside resistance determinant of the Staphylococcus aureus transposon Tn 4001, which specifies resistance to gentamicin, tobramycin and kanamycin, has been cloned and shown to express these resistances in Escherichia coli. The determinant encoded a single protein with an apparent size of $59 \mathrm{kDa}$ which specified both aminoglycoside acetyltransferase [AAC $\left.\left(6^{\prime}\right)\right]$ and aminoglycoside phosphotransferase $\left[\mathrm{APH}\left(2^{\prime \prime}\right)\right]$ activities. Nucleotide sequence analysis of the determinant showed it to be capable of encoding a 479-amino-acid protein of $56.9 \mathrm{kDa}$. Analysis of Tn 1725 insertion mutants of the determinant indicated that resistance to tobramycin and kanamycin is due to the AAC activity specified by, approximately, the first 170 amino acids of the predicted protein sequence and is consistent with the gentamicin resistance, specified by the APH activity, being encoded within the C-terminal region of the protein. Comparison of the $\mathrm{C}$-terminal end of the predicted amino acid sequence with the reported sequences of 13 APHs and a viomycin phosphotransferase revealed a region which is highly conserved among these phosphotransferases.
\end{abstract}

\section{INTRODUCTION}

Enzymic modification of aminoglycosides is a ubiquitous mechanism of resistance to these antibiotics among clinical isolates of both Gram-negative and Gram-positive bacteria. These modifying enzymes can be plasmid- or chromosome-mediated and are often encoded on transposable elements. Three types of enzyme activity are recognized: aminoglycoside- $O$ phosphotransferase (APH), aminoglycoside- $N$-acetyltransferase (AAC), and aminoglycoside$O$-adenyltransferase (AAD). Typically, a particular enzyme catalyses a single type of modification reaction which is capable of inactivating a characteristic subset of the aminoglycosides (for reviews see Bryan, 1984; Phillips \& Shannon, 1984).

An exception to this property is the bifunctional modifying enzyme found in strains of Staphylococcus aureus, Staphylococcus epidermidis (Le Goffic et al., 1977; Martel et al., 1983; Ubukata et al., 1984) and Streptococcus faecalis (Courvalin et al., 1980), which catalyses both 6'acetyltransferase $\left[\mathrm{AAC}\left(6^{\prime}\right)\right]$ and $2^{\prime}$-phosphotransferase $\left[\mathrm{APH}\left(2^{\prime \prime}\right)\right]$ reactions. These activities, which in $S$. aureus are encoded by a determinant designated aac $A-a p h D$ (Lyon \& Skurray, 1987), collectively mediate resistance to the aminoglycosides gentamicin, kanamycin and tobramycin.

The composite transposon Tn4001, which has been responsible for the gentamicin resistance among epidemic strains of $S$. aureus from Australian hospitals (Lyon et al., 1984; Gillespie et al., 1987) and shares homology with a determinant which occurs in isolates from North America (Lyon et al., 1987a), produces a similar resistance pattern to that mediated by AAC $\left(6^{\prime}\right)-\mathrm{APH}\left(2^{\prime \prime}\right)$

† Present address: Department of Biochemistry, Hong Kong University, Hong Kong.

Abbreviations: AAC, aminoglycoside- $N$-acetyltransferase; AAD, aminoglycoside- $O$-adenyltransferase; APH, aminoglycoside- $O$-phosphotransferase; SPH, streptomycin phosphotransferase; VPH, viomycin phosphotransferase; URF, unidentified reading frame. 
activity; Tn 4001 may, therefore, encode an AAC (6')-APH(2") bifunctional enzyme. Support for this hypothesis, and further information on the genetic basis of the two enzyme activities, is provided by the structural and expression analysis of the Tn 4001 aminoglycoside resistance determinant presented here.

\section{METHODS}

Bacterial strains and plasmids. The S. aureus strains used were: SK982 (rifampicin ${ }^{\mathrm{r}}$, novobiocin ${ }^{\mathrm{r}}$ ), Lyon et al. (1984); SK2201 = SK982 carrying plasmid pSK1 [gentamicin $\left(\mathrm{Gm}^{r}\right)$, tobramycin ${ }^{r}\left(\operatorname{Tm}^{r}\right)$, kanamycin ${ }^{r}\left(\mathrm{Km}^{r}\right)$, trimethoprim $^{r}$, acriflavine ${ }^{r}$, ethidium bromider ${ }^{r}$, quaternary ammonium compound ${ }^{r}$ ], Lyon et al. $(1987 b)$; SH6 carrying plasmid pSH6 $\left(\mathrm{Gm}^{r} \mathrm{Tm}^{r} \mathrm{Km}^{\mathrm{r}}\right)$, McDonnell et al. $(1983) ; \mathrm{RN} 2397=\mathrm{RN} 450$ carrying plasmid pUB110 [neomycin ${ }^{r}\left(\mathrm{Nm}^{r}\right) \mathrm{Km}^{\mathrm{r}}$ ], Novick et al. (1981). The Escherichia coli host strains employed were: JM101, supE thi $\triangle\left(\right.$ lac-proAB) [ $\mathrm{F}^{\prime}$ traD36 proAB lacI ${ }^{9} \triangle($ lacZ)M15], Yanisch-Perron et al. (1985); MC1022, araD$139 \Delta$ (ara-leu)7697 galU galK strA $\triangle\left(\right.$ lacZ)M15, Casadaban \& Cohen (1980); CSR603, $\mathrm{F}^{-}$thr-1 leuB6 proA2 hisG4 argE3 thi-1 ara-14 lacYl galK xyl-5 mtl-1 rpsL31 tsx-33 supE44 sup-37 phr-1 recAl uvr-6, Sancar et al. (1979). E. coli plasmids used or constructed in this study are listed in Table 1.

Recombinant DNA techniques. Construction of recombinant DNAs was according to Ray \& Skurray (1983). DNA manipulations were performed with $\mathrm{C} 1$ physical containment as laid down by the Recombinant DNA Monitoring Committee, Australia.

Tn1725 mutagenesis. Transposon mutagenesis, using an $\mathrm{F}_{\mathrm{is}} l a c^{+}$plasmid which carried $\mathrm{Tn} 1725$, was performed as described previously (Cram et al., 1984) except that the $r e c A^{+}$strain $\mathrm{MCl} 022$ was used for mutagenesis and ampicillin (Ap) was used to select for the target plasmid, pSK330.

Aminoglycoside-modifying enzyme assays. APH, AAC and AAD activities were assayed by the method of Shannon \& Phillips (1983). Enzymic activities were measured as the amount of radio-labelling of an aminoglycoside mediated by the cell-extract of a plasmid-bearing strain after subtraction of the value for the parental strain alone. RN2397(pUB110), which encodes an $\operatorname{AAD}\left(4^{\prime}\right)\left(4^{\prime \prime}\right)$ activity (Sadaie et al., 1980), served as a

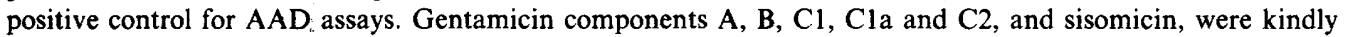
donated by the Schering Corporation. Amikacin, kanamycin A and kanamycin B were a gift from Bristol-Myers Pty Ltd. Neomycin B and neomycin C were a gift from Upjohn Pty Ltd. Warner-Lambert Co. donated paromomycin.

Maxicell analysis of plasmid-encoded proteins. Plasmid-encoded proteins were analysed using the maxicell expression system of Sancar et al. (1979), with CSR603 as the host strain. The $\left[{ }^{35}\right.$ S]methionine labelling of proteins, SDS-PAGE and subsequent autoradiography were as previously described (Ray \& Skurray, 1983). Protein standards were: bovine serum albumin, $67.0 \mathrm{kDa}$; ovalbumin, $43.0 \mathrm{kDa}$; carbonic anhydrase, $30.0 \mathrm{kDa}$; soybean trypsin inhibitor, $20.0 \mathrm{kDa} ; \beta$-lactalbumin, $14.4 \mathrm{kDa}$.

Nucleotide sequencing. DNA nucleotide sequence was determined with $\left[{ }^{35}\right.$ S $] \mathrm{dCTP}$ label (Amersham), by the dideoxy chain termination method of Sanger et al. (1977) using restriction fragments cloned into the M13 derivatives mp8 and mp9 (Messing, 1983) or pUC8. Plasmid DNA templates were prepared according to Azad et

Table 1. E. coli plasmids

Plasmid

$\begin{array}{ll}\text { pACYC184 } & \mathrm{Cm}^{r} \mathrm{Tc}^{\mathrm{r}} \text { vector } \\ \text { pUC8 } & \mathrm{Ap}^{\mathrm{r}} \text { vector } \\ \text { pPV33-H } & \text { Promotor-probe vector } \\ F_{\text {ts }} l a c^{+}:: \operatorname{Tn} 1725 & \mathrm{Tn} 1725 \text { carrier }\end{array}$

pSK 310

pSK330

pSK 343-pSK 365

pSK 483

pSK484

pSK 489

pSK 491

pSK492

pSK493
Description*

pSK1 HindIII D fragment in pACYC184

pSK 1 HindIII D fragment in pUC8

Indepentent $\mathrm{Tn} 1725$ insertion derivatives of pSK 330

Deletion derivative of pSK 344

Deletion derivative of $\mathrm{pSK} 345$

Deletion derivative of pSK 353

Deletion derivative of pSK 355

Deletion derivative of pSK 358

Deletion derivative of pSK 359

\section{Reference/source}

Chang \& Cohen (1978)

Messing \& Vieira (1982)

West \& Rodriguez (1982)

P. Reeves

Lyon et al. (1987)

This study

This study

This study

This study

This study

This study

This study

This study

${ }^{*} \mathrm{Cm}^{\mathrm{r}}, \mathrm{Tc}^{\mathrm{r}}$ and $\mathrm{Ap}^{\mathrm{r}}$ indicate that resistance is specified to chloramphenicol, tetracycline and ampicillin, respectively. 
al. (1985) and subjected to alkali denaturation prior to sequencing (Chen \& Seeburg, 1985). Sequence analysis was performed using the programs of Garnier et al. (1978) and Staden (1986) as modified by R. Maxwell (Department of Biochemistry, Monash University) and A. Kyne (Walter and Eliza Hall Institute of Medical Research, Melbourne, Australia), respectively; protein secondary structures were predicted by the algorithm of Robson (Garnier et al., 1978).

\section{RESULTS}

\section{Expression of Tn4001-encoded aminoglycoside resistance in E. coli}

The aminoglycoside-resistance determinant of Tn 4001 present on the multiresistant $S$. aureus plasmid pSK 1 has been cloned on a $2.5 \mathrm{~kb}$ HindIII fragment into pACYC184, forming the plasmid pSK 310 (Lyon et al., 1987a). This HindIII fragment, which consists of the $1.9 \mathrm{~kb}$ unique region flanked by $0.3 \mathrm{~kb}$ of each of the $1.35 \mathrm{~kb}$ IS256 copies contained within Tn4001 (Lyon \& Skurray, 1987; Lyon et al., 1987b), was subcloned from pSK310 into pUC8, to form plasmid pSK330 (Table 1). The E. coli strain MC1022 harbouring pSK330 expressed $\mathrm{Gm}^{\mathrm{r}}, \mathrm{Tm}^{\mathrm{r}}$ and $\mathrm{Km}^{\mathrm{r}}$ at similar levels to those of the $S$. aureus strain SK2201, which carries Tn4001 located on pSK1; minimum inhibitory concentration (MIC) values for $\mathrm{Gm}$, Tm and $\mathrm{Km}$ for MC1022(pSK330) were 16,32 and $256 \mu \mathrm{g} \mathrm{ml}^{-1}$, respectively. Furthermore, the $2.5 \mathrm{~kb} H$ indIII fragment, when recloned into the promoter-probe vector pPV33-H (West \& Rodriguez, 1982), conferred a similar level of resistance to that of pSK330, irrespective of its orientation (data not shown). Since transcriptional activity does not cross the cloning site in pPV33-H, the elements required for $\mathrm{Gm}^{\mathrm{r}}, \mathrm{Tm}^{\mathrm{r}}$ and $\mathrm{Km}^{\mathrm{r}}$ expression in E. coli are contained within the $2.5 \mathrm{~kb}$ HindIII fragment.

\section{Tn1725 insertion mutagenesis and deletion analysis}

In order to define the functional areas within the $2.5 \mathrm{~kb}$ HindIII fragment necessary for expression of $\mathrm{Gm}^{\mathrm{r}}, \mathrm{Tm}^{\mathrm{r}}$ and $\mathrm{Km}^{\mathrm{r}}$, pSK 330 (Table 1) was subjected to Tn 1725 mutagenesis. Of the 22 independent insertion derivatives obtained (designated pSK 343 to pSK365), 18 possessed insertions within the cloned HindIII fragment and produced four phenotypic mutant classes (Fig. 1, top): (i) insertions at either end of the clone within IS256 sequences had no apparent effect on resistance, (ii) insertions between the arbitrary $H$ indIII fragment coordinates $0 \cdot 85-1 \cdot 20$ resulted in a $\mathrm{Gm}^{\mathrm{s}} \mathrm{Tm}^{\mathrm{s}} \mathrm{Km}^{\mathrm{s}}$ phenotype, (iii) insertions between coordinates $1 \cdot 25-2 \cdot 10$ gave a $\mathrm{Gm}^{\mathrm{s}} \mathrm{Tm}^{\mathrm{r}} \mathrm{Km}^{\mathrm{r}}$ phenotype, and (iv) insertions mapping between coordinates $0.45-0.70$ produced a low level of resistance to all three aminoglycosides (MICs being 4, 8 and $32 \mu \mathrm{g} \mathrm{ml}^{-1}$ for $\mathrm{Gm}$, $\mathrm{Tm}$ and $\mathrm{Km}$, respectively). From these results the minimum span of the coding region for $\mathrm{Tm}^{\mathrm{r}}$ and $\mathrm{Km}^{\mathrm{r}}$ is $0.35 \mathrm{~kb}$ (coordinates $0.85-1.20$; delineated by the insertions in pSK 352 and pSK356) and the maximum span lies between coordinates $0 \cdot 70-1 \cdot 25$ (defined by pSK351 and pSK358).

Since transcription of the area encoding the three aminoglycoside resistances most probably occurs from left to right in Fig. 1 (see below), Tn1725 insertions that are located between coordinates $0 \cdot 85-2 \cdot 10$ and resulted in loss of $\mathrm{Gm}^{\mathrm{r}}$ (with or without corresponding loss of $\mathrm{Tm}^{\mathrm{r}}$ and $\mathrm{Km}^{\mathrm{r}}$ ), may have done so for two possible reasons: they may have occurred within the structural coding region for $\mathrm{Gm}^{\mathrm{r}}$, or, alternatively, blocked transcription into this region. The low level of resistance to all three aminoglycosides resulting from the $\mathrm{Tn} 1725$ insertions between coordinates $0 \cdot 45-0.70$ suggests that these insertions fall not within the structural coding regions, but within a region necessary for their normal expression.

To further clarify the extent of DNA required for the normal expression of aminoglycoside resistance, a series of deletions, starting at the left-hand end of the HindIII fragment (coordinate $0 \cdot 0$ ), were constructed (Fig. 1, bottom). These were produced from plasmids containing Tn 1725 insertions, by deleting the region between the EcoRI site in the pUC8 vector moiety (adjacent to the HindIII site at coordinate $0 \cdot 0$ ) and the rightmost EcoRI sites of the Tn 1725 ; only 18 bp of the $\operatorname{Tn} 1725$ sequence remained after deletion (Ubben \& Schmitt, 1986). pSK483, with a deletion spanning coordinates $0 \cdot 0-0 \cdot 20$, conferred wild-type resistance. In contrast, pSK484, with a deletion between coordinates $0 \cdot 0-0 \cdot 45$, demonstrated approximately 20 -fold lower MICs for $\mathrm{Gm}, \mathrm{Tm}$ and $\mathrm{Km}$. Plasmids with larger deletions were sensitive to all three aminoglycosides. 


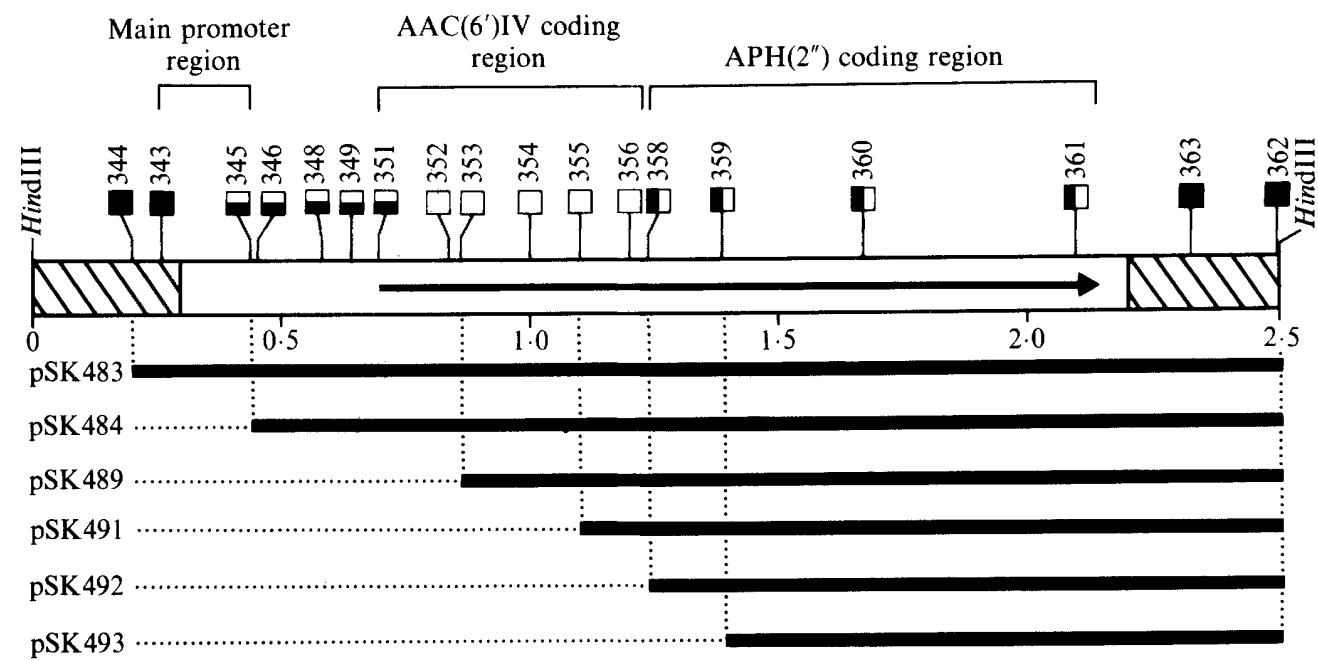

Fig. 1. Tn1725 insertion map and deletion analysis of the Tn4001 aminoglycoside determinant. The arrow indicates the long open reading frame determined from the sequence of the $2.5 \mathrm{~kb}$ HindIII fragment from Tn4001. The IS256 sequences present on the fragment are shown as the hatched areas. Tn1725 insertion points are marked by the squares, with associated plasmid (pSK) numbers. The phenotypes of the $\operatorname{Tn} 1725$ mutants, shown within the squares, are: $\square$, wild-type resistance; $\square$, $\mathrm{Gm}^{\mathrm{s}} \mathrm{Tm}^{\mathrm{s}} \mathrm{Km}^{\mathrm{s}}$;, , low-level resistance to $\mathrm{Gm}, \mathrm{Tm}$ and $\mathrm{Km} ; \mathbf{\square}, \mathrm{Gm}^{\mathrm{s}} \mathrm{Tm}^{\mathrm{r}} \mathrm{Km}^{\mathrm{r}}$. Plasmids with $5^{\prime}$ deletions of the $2.5 \mathrm{~kb}$ HindIII fragment contained in pSK330 are designated at the lower left; the remainder of the insert fragment left after deletion is indicated. Marked at the top are the main promoter region for the determinant and the AAC $\left(6^{\prime}\right) \mathrm{IV}$ and $\mathrm{APH}\left(2^{\prime \prime}\right)$ coding regions inferred from this and other experiments described in this study.

The region spanning coordinates $0 \cdot 20-0 \cdot 45$, then, is important for the expression of aminoglycoside resistance, suggesting that it may contain promoter elements. The level of resistance conferred by the deletion plasmid pSK 484 was fivefold lower than that of its parental plasmid, pSK 345; the higher resistance encoded by the latter may be due to weak promoter activity from $\mathrm{Tn} 1725$ directing transcription of the aminoglycoside-resistance-coding regions.

\section{Maxicell analysis of plasmid products}

The maxicell expression system was employed to examine the products encoded by the cloned HindIII fragment and selected Tn 1725 mutants (Fig. 2). Maxicells which contained plasmids conferring wild-type resistance, viz. pSK330, pSK365 (pSK330 with Tn1725 inserted in the vector moiety), pSK 343 , and pSK 362, produced a single insert-specific protein, estimated to be $59 \mathrm{kDa}$ in size (lanes $\mathrm{B}, \mathrm{C}, \mathrm{D}$ and $\mathrm{L}$, respectively), suggesting that the $\mathrm{Gm}^{\mathrm{r}}, \mathrm{Tm}^{\mathrm{r}}$ and $\mathrm{Km}^{\mathrm{r}}$ are specified by a single protein. In contrast, maxicells containing pSK348, which mediated lowlevel resistance to $\mathrm{Gm}, \mathrm{Tm}$ and $\mathrm{Km}$, produced the $59 \mathrm{kDa}$ protein at a markedly reduced level (lane E), as did pSK351 (data not shown), indicating that the low-level resistance phenotype may result from reduced synthesis of the $59 \mathrm{kDa}$ protein.

A number of the plasmids in which a Tn1725 insertion caused complete loss of one or more aminoglycoside resistances, e.g. pSK355, pSK356, pSK359 and pSK360 (lanes G, H, I, J), did not direct synthesis of the $59 \mathrm{kDa}$ protein, but specified unique proteins of $18,20 \cdot 5,31$ and $38 \mathrm{kDa}$, respectively. These products appear to be truncated forms of the $59 \mathrm{kDa}$ protein. Given this, the concordant increase in size of the protein produced with increased distance of the site of Tn 1725 insertion from the left, in Fig. 1, indicates that the direction of transcription and translation of the $59 \mathrm{kDa}$ protein is from left to right. pSK361, which gave a $\mathrm{Gm}^{\mathrm{s}} \mathrm{Tm}^{\mathrm{r}} \mathrm{Km}^{\mathrm{r}}$ phenotype, still encoded a polypeptide of approximately $59 \mathrm{kDa}$ (lane $\mathrm{K}$ ), probably due to the insertion of Tn 1725 near the end of the coding region. This is consistent with the position of the open reading frame defined by the nucleotide sequence analysis (Figs 1 and 4). Two plasmids 


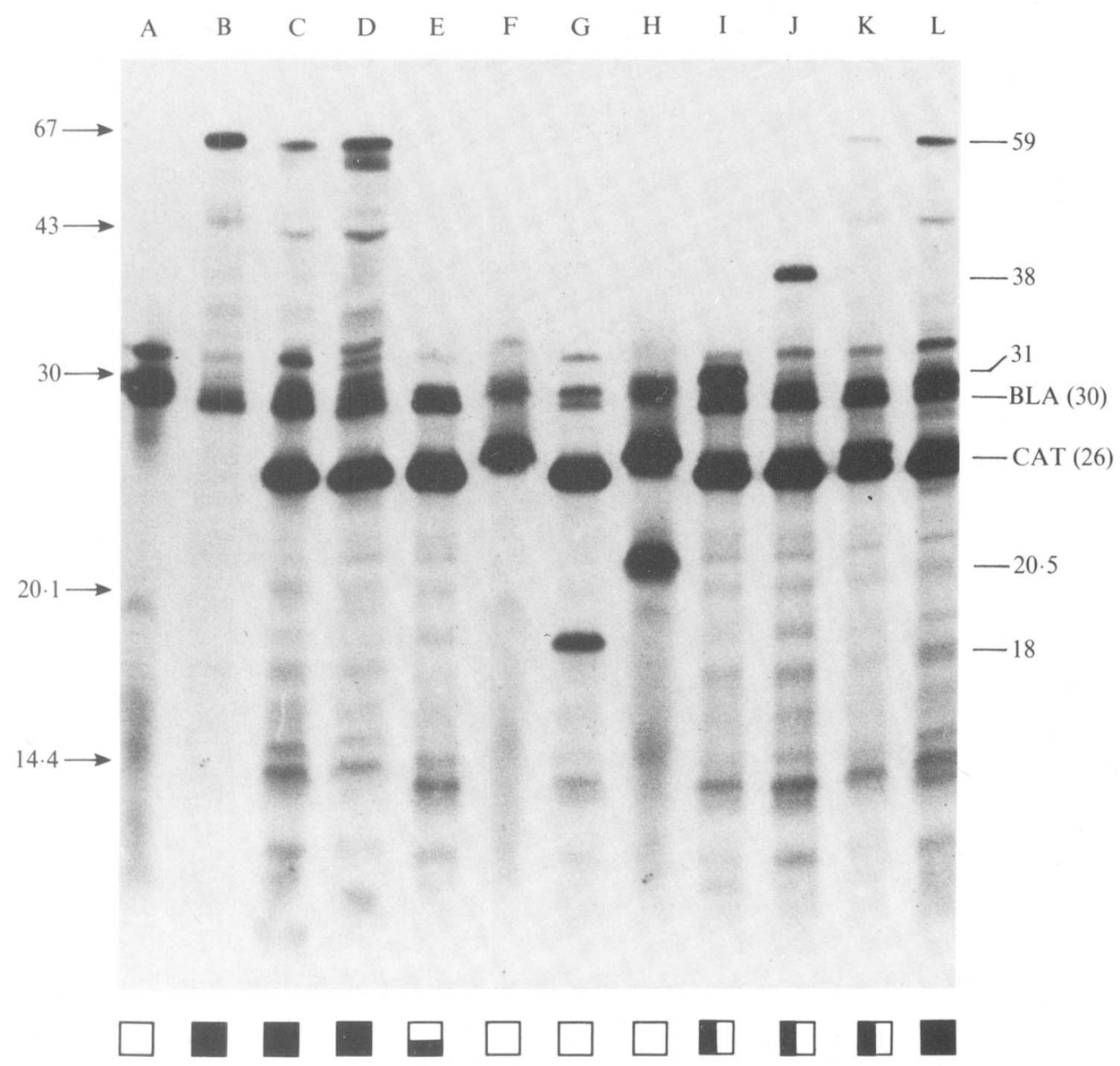

Fig. 2. Autoradiograph of $\left[{ }^{35} \mathrm{~S}\right]$ methionine-labelled polypeptides in lysates of maxicells harbouring: pUC8 (lane A), pSK 330 (lane B), pSK365 (lane C), pSK 343 (lane D), pSK348 (lane E), pSK 353 (lane F), pSK 355 (lane G), pSK356 (lane H), pSK359 (lane I), pSK360 (lane J), pSK361 (lane K), pSK362 (lane $\mathrm{L}$ ). The migration positions of protein standards of the indicated sizes (kDa) are shown at the left. The sizes $(\mathrm{kDa})$ of the plasmid-encoded polypeptides, including the $\beta$-lactamase (BLA) of pUC8 and the chloramphenicol acetyltransferase (CAT) of Tn1725, are indicated on the right. The aminoglycoside resistance phenotypes are summarized at the bottom; symbols are as defined in Fig. 1.

specifying $\mathrm{Gm}^{\mathrm{s}} \mathrm{Tm}^{\mathrm{s}} \mathrm{Km}^{\mathrm{s}}$ phenotypes, pSK353 (lane F) and pSK354 (data not shown), failed to direct the synthesis of any detectable unique proteins. This may be due to synthesis of a product too small to be detected, since the insertions in these plasmids are close to the proposed translation initiation site for the $59 \mathrm{kDa}$ protein.

\section{Assay of aminoglycoside-modifying enzymes}

The similarity of the resistance pattern specified by $\mathrm{Tn} 4001$ to that conferred by the AAC $\left(6^{\prime}\right)$ and $\mathrm{APH}\left(2^{\prime \prime}\right)$ activities encoded by $S$. aureus plasmids such as pSH6 (McDonnell et al., 1983) suggested that Tn 4001 might encode for similar aminoglycoside-modifying activities. To verify this notion, assays of aminoglycoside-modifying enzymes were performed on both $S$. aureus and $E$. coli strains harbouring plasmids carrying the determinant (Table 2). Plasmids pSK 1 (which carries Tn400I) and pSH6 both conferred substrate profiles specifically indicative of AAC(6')IV and APH $\left(2^{\prime \prime}\right)$ activities (Foster, 1983); neither specified any significant AAD activity (data not shown). The E. coli recombinant plasmid pSK330, containing the resistance determinant of Tn4001, produced AAC and APH substrate profiles essentially similar to those of pSK1, but 
Table 2. Assay of aminoglycoside-modifying enzymes

\begin{tabular}{|c|c|c|c|c|c|c|c|c|c|c|c|c|c|c|c|}
\hline \multirow{2}{*}{$\begin{array}{l}\text { Assay } \\
\text { for: }\end{array}$} & \multirow[b]{2}{*}{ Plasmid/host } & \multicolumn{14}{|c|}{ Enzyme modification activity against*: } \\
\hline & & $\mathrm{GmA}$ & $\mathrm{GmB}$ & $\mathrm{GmCl}$ & $\mathrm{GmCla}$ & $\mathrm{GmC2}$ & $\mathrm{Si}$ & Ak & $\mathrm{Tm}$ & $\mathrm{KmA}$ & $\mathrm{KmB}$ & $\mathrm{NmB}$ & $\mathrm{NmC}$ & $\mathrm{Pm}$ & $\mathrm{Sm}$ \\
\hline \multirow{6}{*}{ APH } & pSK 1/SK982 & $\mathbf{M}$ & L & M & $\mathbf{M}$ & $\mathbf{L}$ & M & $\mathbf{M}$ & - & - & $\mathbf{L}$ & - & - & - & - \\
\hline & pSH6/SH6 & $\mathbf{M}$ & L & M & $\mathbf{M}$ & $\mathbf{L}$ & M & $\mathbf{L}$ & - & - & $\mathbf{L}$ & - & - & - & - \\
\hline & pSK $330 / \mathrm{MC} 1022$ & M & M & M & $\mathbf{M}$ & $\mathbf{M}$ & M & $\mathbf{M}$ & - & - & $\mathrm{L}$ & - & - & - & - \\
\hline & pSK344/JM I01 & M & M & & & & & & & & & & & & \\
\hline & pSK 353/JM10I & - & - & & & & & & & & & & & & \\
\hline & pSK 360/JM101 & - & - & & & & & & & & & & & & \\
\hline \multirow[t]{6}{*}{$\mathrm{AAC}$} & pSK1/SK 982 & & & $L$ & $\mathbf{M}$ & - & 1 & $\mathbf{L}$ & $\mathrm{H}$ & $\mathbf{H}$ & $\mathbf{H}$ & $\mathbf{L}$ & & & \\
\hline & pSH6/SH6 & & & $\mathrm{L}$ & $\mathbf{M}$ & - & $\mathbf{L}$ & L & $\mathbf{H}$ & $\mathbf{H}$ & $\mathbf{H}$ & L & & & \\
\hline & pSK 330/MC1022 & & & $\mathbf{M}$ & $\mathbf{M}$ & $\mathbf{L}$ & $\mathbf{L}$ & L & H & $\mathbf{H}$ & $\mathbf{H}$ & $\mathrm{L}$ & & & \\
\hline & pSK 344/JM101 & & & & $\mathbf{M}$ & & & & $\mathbf{H}$ & $\mathbf{H}$ & & & & & \\
\hline & pSK 353/JMI01 & & & & - & & & & - & - & & & & & \\
\hline & pSK 360/JM101 & & & & $\mathbf{M}$ & & & & $\mathbf{H}$ & $\mathbf{H}$ & & & & & \\
\hline
\end{tabular}

\footnotetext{
- Assays for APH and AAC modification of the aminoglycoside indicated were performed twice; duplicates were within $20 \%$ of each other. Average enzyme activities are shown: -, negative, 0-99 c.p.m.; L, low, 100-299 c.p.m.; M, medium, 300-999 c.p.m.; H, high, 1000-3000 c.p.m. Blank spaces denote reactions not tested. Abbreviations: $\mathrm{GmA}, \mathrm{GmB}, \mathrm{GmCl}, \mathrm{GmCla}, \mathrm{GmC}$, gentamicin components; $\mathrm{Si}$, sisomicin; Ak, amikacin; Tm, tobramycin; KmA, KmB, kanamycin components; $\mathrm{NmB}, \mathrm{NmC}$, neomycin components; Pm, paromomycin; Sm, streptomycin.
}

activities were in general slightly elevated. The resistance determinant of Tn 4001 appears, therefore, to encode both $\mathrm{AAC}\left(6^{\prime}\right)$ and $\mathrm{APH}\left(2^{\prime \prime}\right)$ activities only and has, accordingly, been designated aacA-aphD.

Examination of the enzyme substrate profiles (Table 2) suggested that the AAC activity conferred $\mathrm{Tm}^{\mathrm{r}}$ and $\mathrm{Km}^{\mathrm{r}}$, and that the APH activity conferred $\mathrm{Gm}^{\mathrm{r}}$. These associations were investigated further by determination of the enzyme activities specified by different classes of the Tn 1725 mutants. pSK $360\left(\mathrm{Gm}^{\mathrm{s}} \mathrm{Tm}^{\mathrm{s}} \mathrm{Km}^{\mathrm{s}}\right)$ specified AAC but not APH activity, whereas pSK353 $\left(\mathrm{Gm}^{\mathrm{s}} \mathrm{Tm}^{\mathrm{r}} \mathrm{Km}^{\mathrm{r}}\right)$ did not confer AAC or APH activity. The activities of pSK344 $\left(\mathrm{Gm}^{\mathrm{r}} \mathrm{Tm}^{\mathrm{r}} \mathrm{Km}^{\mathrm{r}}\right)$ were similar to those specified by pSK330, indicating that $\mathrm{Tn} 1725$ insertion per $s e$ had no effect. Taken together, these results are consistent with $\mathrm{Tm}^{\mathrm{r}}$ and $\mathrm{Km}^{\mathrm{r}}$ being due to AAC activity and with the APH activity being responsible for the $\mathrm{Gm}^{\mathrm{r}}$.

\section{Nucleotide sequence of the aminoglycoside-resistance determinant}

To further delineate the functional regions within the aac $A-a p h D$ determinant, the nucleotide sequence of the $2.5 \mathrm{~kb}$ HindIII fragment encompassing the determinant was obtained from subclones of pSK 330 derivatives containing Tn 1725 insertions. The sequencing strategy is shown in Fig. 3. This strategy made use of the inserted $\operatorname{Tn} 1725$ copies as each effectively constituted a new EcoRI site, thereby facilitating subcloning (Ubben \& Schmitt, 1986).

The sequence (Fig. 4) contains an open reading frame, bp 700-2136, of sufficient size to encode a 479 -amino-acid protein of $56850 \mathrm{Da}$. This open reading frame appears to be the structural coding region for aminoglycoside resistance since $\mathrm{Tn} 1725$ insertions which resulted in complete loss of resistance to one or all aminoglycosides mapped within it (Fig. 1). Furthermore, the sizes of the normal and apparent truncated forms of this protein (specified by pSK 330 and $\operatorname{Tn} 1725$ insertion derivatives of it) predicted from the sequence were comparable to those produced in maxicells (Table 3). For the prediction of protein sizes the contribution of Tn 1725 sequences was taken into account since the translation stop codons for the reading frames entering Tn 1725 occur at significant distances from the ends of the transposon (the same as for Tn1721; Schoffl et al., 1981). The hydrophilicity along the primary structure of the deduced aac $A-a p h D$ product was evenly distributed, with no large hydrophobic regions (data not shown), which is typical of soluble proteins, and is consistent with the proposed cytoplasmic location for aminoglycoside-modifying enzymes (Foster, 1983).

The coding region which specifies the AAC activity $\left(\mathrm{Tm}^{\mathrm{r}} \mathrm{Km}^{\mathrm{r}}\right)$ within the aacA-aphD determinant, as deduced from the $\mathrm{Tn} 1725$ insertion mutagenesis, occurs at a minimum between bp 846-1200 and at a maximum between bp 700-1245 (Figs 1 and 4). These occur in the 5'proximal region of the aacA-aphD coding frame and thus the AAC activity is specified by between 167 and 180 amino acids at the $\mathrm{N}$-terminal end of the deduced aacA-aphD product. 


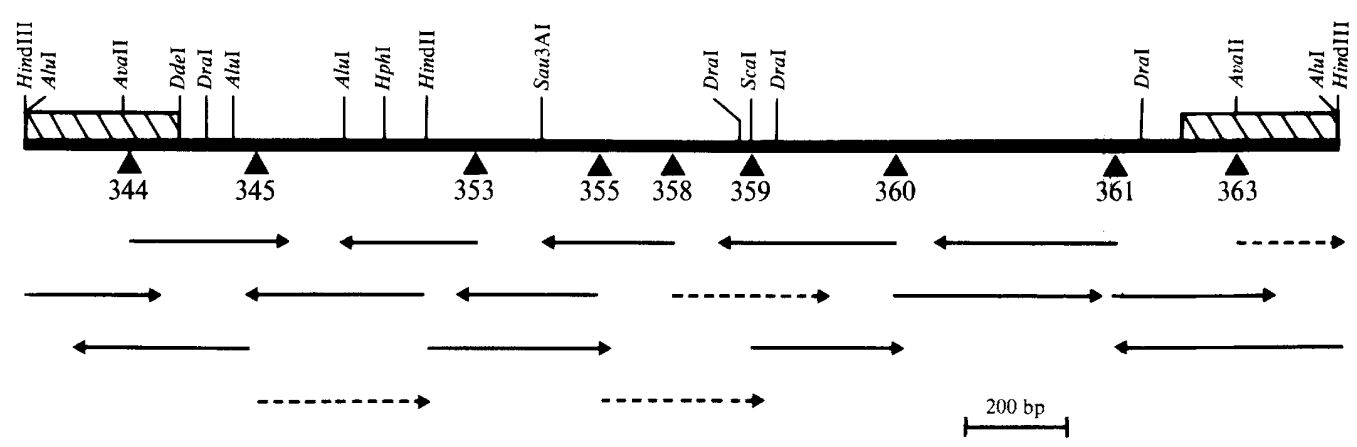

Fig. 3. Sequencing strategy and partial restriction map of the $2.5 \mathrm{~kb}$ HindIII fragment of Tn 4001 . The positions of the Tn 1725 insertions used to facilitate subcloning for sequencing (see text) are marked by triangles; hatched areas denote the inverted IS256 sequences. Solid and dashed arrowed lines below the map depict the extent and direction of sequences obtained from M13 and pUC8 recombinants, respectively.

Table 3. Observed and expected sizes of truncated AacA-AphD polypeptides

\begin{tabular}{|c|c|c|}
\hline \multirow[b]{2}{*}{ Plasmid } & \multicolumn{2}{|c|}{ Polypeptide size (kDa) } \\
\hline & $\begin{array}{l}\text { Inferred from } \\
\text { DNA sequence* }\end{array}$ & Observed $\dagger$ \\
\hline pSK 355t & $18 \cdot 9$ & 18 \\
\hline pSK356‡ & $22 \cdot 9$ & $20 \cdot 5$ \\
\hline pSK359‡ & $32 \cdot 9$ & 31 \\
\hline pSK $360 \ddagger$ & $40 \cdot 7$ & 38 \\
\hline pSK $361 \ddagger$ & $57 \cdot 9$ & 59 \\
\hline pSK 330 & $56 \cdot 8$ & 59 \\
\hline
\end{tabular}

\footnotetext{
* In calculation of the expected polypeptide sizes the translation start point was taken as bp 700 in the nucleotide sequence of the $2.5 \mathrm{~kb}$ HindIII fragment (Fig. 4); the translation end point for the $\mathrm{Tn} I 725$ insertion derivatives was determined from the sequenced site of insertion, as shown in Fig. 4, accounting for translation read-through into $\operatorname{Tn} 1725$ (see text), with the exception of pSK356, where the site of $\operatorname{Tn} 1725$ insertion was determined by restriction mapping and the contribution of $\operatorname{Tn} 1725$ sequences to the expected polypeptide size was taken as the average of that predicted for the different reading frames.

$\uparrow$ Sizes of polypeptides produced in maxicells, as described in Fig. 2.

$\ddagger$ Derivative of pSK 330 with a Tn 1725 insertion causing an altered aminoglycoside resistance phenotype, as described in Figs 1 and 4.
}

Within the HindIII fragment is an unidentified reading frame (URF), $5^{\prime}$ to aacA-aphD between bp $370-696$, capable of encoding a protein of $12.6 \mathrm{kDa}$. Both the aac $A$-aphD reading frame and the URF, which read in the same direction, are preceded by strong ribsome-binding sites that are typical of genes from Gram-positive bacteria (McLaughlin et al., 1981).

Upstream from the aacA-aphD coding frame are three strong potential promoter sequences. In order of decreasing fit to the $E$. coli promoter consensus sequence, which is the same as that of Gram-positive bacteria (McLaughlin et al., 1981; Moran et al., 1982), these are P1, P2 and P3 (Fig. 4). For example, P1 shows a five-out-of-six fit to the consensus for both the -35 and -10 boxes [the consensus being TTGACA and TATAAT, respectively (Rosenberg \& Court, 1979)] and has the optimal spacing of $17 \mathrm{bp}$ between them. Both P1 and P2 occur upstream from the URF, which precedes the aacA-aphD reading frame. So, a polycistronic mRNA, encompassing the URF and $a a c A-a p h D$ coding region, could possibly be initiated from P1 or P2. Interestingly, the P1 sequence lies across the boundary between the left IS256 inverted repeat and the unique central region of Tn4001 (Fig. 4). 
Hind III

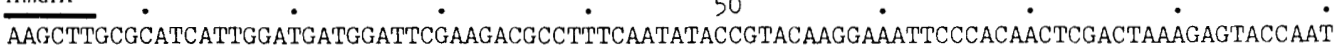

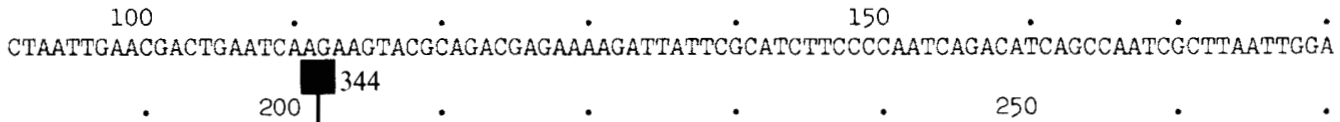
GCCGTTCTTATGGACCTACATGATGAATGGATTTATTCTTCAAGAAAATACATCAATT'PTGATAAGTAGAAATGGTAAAAACATTGTATA \begin{tabular}{lllllllll}
\hline & -35 & P1 & -35 & -10 & -35 & P2 & -10 & RBS
\end{tabular} GCATTTTACACAGGAGTCTGGACTTGACTGAGTT'TATGGAAGAAGTTTTAATTGATGATAATATGGTTTTTGATATTGATAATTTA $\overline{A A A G}$

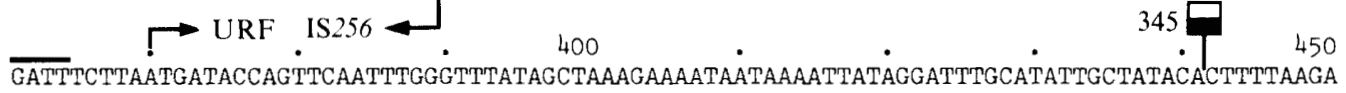
Met IleProValGinPheGly Phe IleAlaLysGluAsnAsnLys IleIleGly PheAla Ty rCys Ty ThrLeuLeuArg

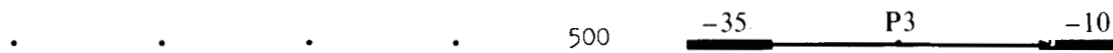

CCTGATGGAAAAACAATGTTMTATTTACACTCAATAGGAATGTTACCTAACTATCAAGACAAAGGTTATGGTTCAAAATTATTATCTTT'T ProAspGly Ly SThMet PheTy rLeuHisSerI leGlyMetLeu ProAsnTy rGInAspLy SGlyTy rGI ySerLys LeuLeuSerPhe

ATTAAGGAATATTCTAAAGAGATTGGTTGTTCTGAAATGTTTTTAATAACTGATAAGGGTATCCTAGAGCTTGCCATGTATATGAAAA

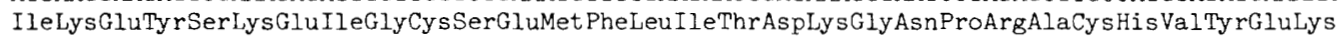

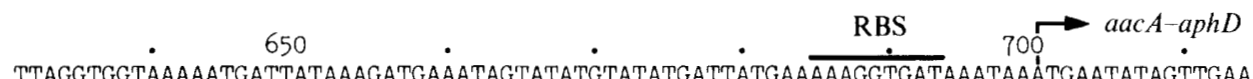
TTAGGTGGTAAAATGATTATAAAGATGAAATAGTATATG'TATATGATTATGAAAAAGGTGATAAATAAATGAATATAG'TGAAAATGAA LeuGlyGly Ly sAsnAs PTy rLy SAs pGluI l eValTy rValTyrAspTy rGluLy sGlyAspLys ***MetAsn I leValGluAsnGlu

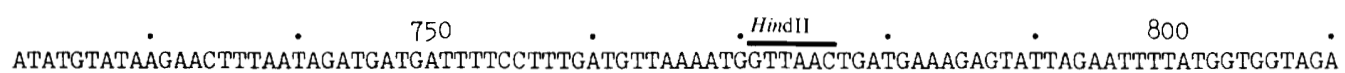
IleCys IleArgThrLeuIl eAspAspAsp PheProLeuMetLeuLys TrpLeuThrAspGIuArgVal LeuGluPheTy rGlyGlyArg GATAAAAAATATACATTAGAATCATTAAAAAAACATTATACAGAGCCTTGGGAAGATGAAGTTTTTAGAGTAATTATTGAATATAACAAT

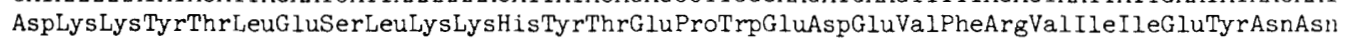

GTTCCTATTGGATATGGACAAATATATAAAATGTATGATGAGTTATATACTGATTATCATTATCCAAAAACTGATGAGATAGTCTATGGT ValProIleGlyTyrGlyGlnIleTyrLysMetTy

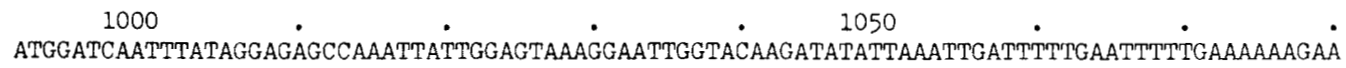
MetAspGlnPheIleGlyGluProAsnTy rTrpSerLysGIy IleGlyThrArgTyr I leLysLeuIlePheGiuPheLeuLysLysGlu AGAAATGCTAATGCAGTTATTTTAGACCCTCATAAAAATAATCCAAGAGCAATAAGGGCATACCAAAAATCTGGTTTTAGAATTATTGAA ArgAsnAlaAsnAlaVal IleLeuAspProHis Lys AsnAsnProArgAlaIleArgAlaTyrGlnLysSerGlyPheArgIleIleGlu GATTTGCCAGAACATGAATTACACGAGGGCAAAAAAGAAGATTGTTATTTAATGGAATATAGATATGATGATAATGCCACAAATGTTAAG AspLeuProGluHisGluLeuHisGluGlyLys LysGluAspCysTy rLeuMetGIuTyrArgTy

Fig. 4 (continued on facing page). Nucleotide sequence of the $2.5 \mathrm{~kb}$ HindIII fragment of Tn 4001 . The structural coding region for the aminoglycoside resistance gene $a a c A-a p h D$ is from bp $700-2136$ and the unidentified reading frame (URF) is from bp 370-696. Bold lines mark the positions of the putative promoter sequences $(-10$ and -35$)$ constituting $\mathrm{P} 1, \mathrm{P} 2$ and $\mathrm{P} 3$ and potential ribosome-binding sites (RBS) for the resistance gene and the URF. The positions of Tn 1725 insertions mapped by sequencing are indicated by squares and associated (pSK) plasmid numbers; corresponding aminoglycosideresistance phenotype symbols are as shown in Fig. 1. The region of the aacA-aphD predicted amino acid sequence with major homology to those of other APHs (Fig. 5) is underlined. IS256 sequences, which flank the resistance determinant, are also marked. HindIII and HindII restriction sites are shown to facilitate orientation with Fig. 3. 
GCAATGAAA'TATTTAATTGAGCAT'TACTTTGATAATTTCAAAGTAGATAGTATTGAAATAATCGGTAGTGGTTATGATAGTGTGGCA'TA'T AlaMet Lys Ty rLeuIleGluHis'Tyr PheAspAsnPheLysValAspSerIleGluIleIleGlySerGlyTyrAspSerVal AlaTyr 359

TTAG'TTAATAATGAATACATT'TTAAAACAAAATTTAGTACTAATAAGAAAAAGGTTATGCAAAAGAAAAAGCAATATATAATT'TT"TA LeuValAsnAsnGluTyrIlePheLys ThrLys PheSerThrAsnLysLys LysGlyTyrAlaLysGluLysA la IleTyrAsnPheLeu

2450

1500

AATACAAATTTAGAAACTAATGTAAAAATTCCTAATATTGAATATTCGTATATTAGTGATGAATTATCTATACTAGGTTATAAAGAAATT AsnThrAsnLeuGluThrAsnVal Lys IleProAsnIleGluTy rSerTyrIleSerAspGluleuSerIleLeuGly TyrLysGluIle

$$
1550
$$

AAAGGAACT"T"MTTAACACCAGAAATTTATTCTACTATGTCAGAAGAAGAACAAAATTTGTTAAAACGAGATATTGCCAGTTTTT"TAAGA LysGlyThrPheLeuThrProGluIleTyrSerThrMetSerGluGloGluGlnAsnLeuLeuLysArgAspI leAlaSerPheI,euArg CAAATGCACGGTTTAGATTATACAGATATTAGTGAATGTACTATTGATAATAAACAAAATGTATTAGAAGAGTATATATTGTTGCGTGAA GlnMet HisGly LeuAspTy rThrAspIleSerGluCysThrIl eAspAsnLy SGInAsnValLeuGluGluTy rIleLeuLeuArgGlu

• $01750 \quad 0 \quad$ • 1800 ThrIleTyrAsnAspLeuThrAspI leGluLysAspTyrIl eGluSerPheMetGluArgLeuAsnAlaThrThrValPheGluGly Lys

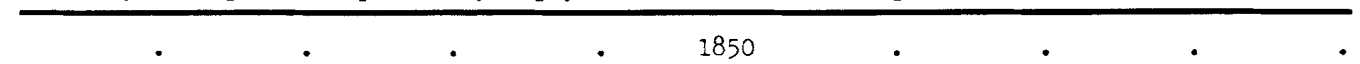
AAGTGTTTATGCCATAATGA'TTTTAGTTGTAATCATCTATTGTTAGATGGCAATAATAGATTAACTGGAATAATTGATTTTGGAGATTCT LysCys LeuCy $\mathrm{H}$ is AsnAsnPheSerCys AsnHis LeuLeuLeuAspGlyAsnAsnArgLeuThrGlyIleIleAsp PheGlyAspSer

$$
1900
$$

- . Gly I leileAspgluTyrCy Asp PheIleTyrLeuLeuGluAspSerGluGluGluIleGlyThrAsnPheGlyGluAspIleLeuArg

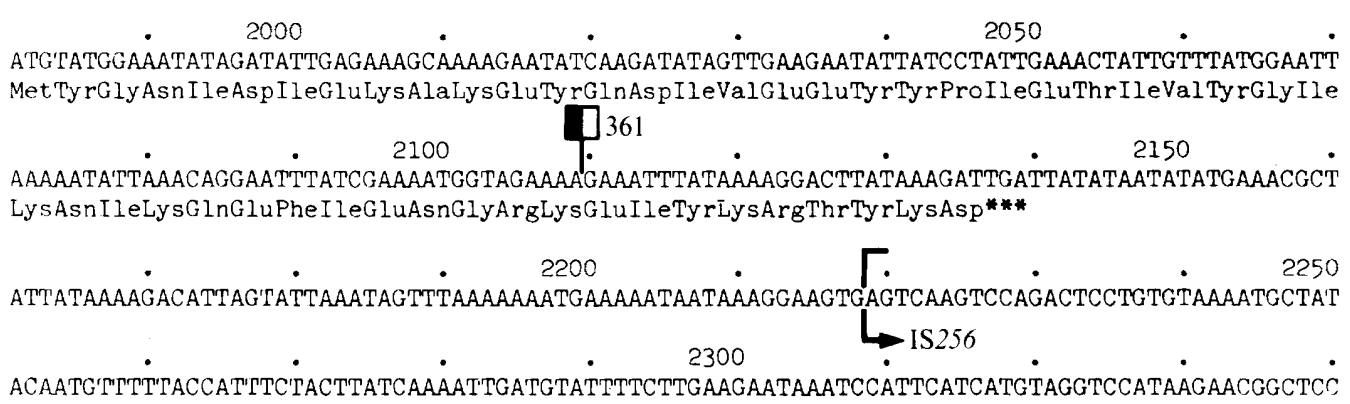

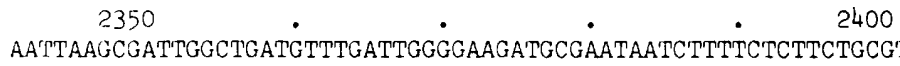 2400

\section{DNA homology}

The nucleotide sequence of the $a a c A-a p h D$ region is almost identical to that of a Streptococcus faecalis plasmid determinant which similarly encodes for AAC $\left(6^{\prime}\right)-\mathrm{APH}\left(2^{\prime \prime}\right)$ activities (Ferretti et al., 1986). Within the sequenced region of the Strep. faecalis determinant, starting at the equivalent of bp 396 of the S. aureus sequence and ending at the right-hand HindIII site, the only differences are a 1 bp deletion in the Strep. faecalis sequence compared to the $S$. aureus sequence at bp 446 and a relative transversion at bp 2157, with A and C occurring in the Strep. faecalis and $S$. aureus sequences, respectively. The deletion causes a frameshift in the URF of one sequence compared to the other, and the base pair difference is downstream from the region encoding the $\mathrm{AAC}\left(6^{\prime}\right)-\mathrm{APH}\left(2^{\prime \prime}\right)$ activities. The inferred primary structures of the $\mathrm{AAC}\left(6^{\prime}\right)-\mathrm{APH}\left(2^{\prime \prime}\right)$ proteins from $S$. aureus and Strep. faecalis are, therefore, identical. 
Enzyme species of origin

AAC(6')IV-APH(2") S. aure'us Strep, faccalis APH(3')(5")I Salmonella typhimurium APH $\left(3^{\prime}\right)\left(5^{\prime \prime}\right) 11 K$. pneumoniac

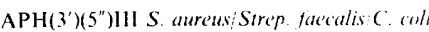
APH $\left(3^{\prime}\right)\left(5^{\prime \prime}\right)$ IV $B$ c circulans

APH $\left(3^{\prime}\right)\left(5^{\prime \prime}\right)$ V Streptomices fradiac APH(4) E. coli

APH(7") Streptomlyces hygroscopicus VPH Streptomyces rinacetus

SPH K. pneamonias

APH(6) Strepiomyces grise'ts

APH(6) Streptomices glatucesecens:
Conserved amino acids

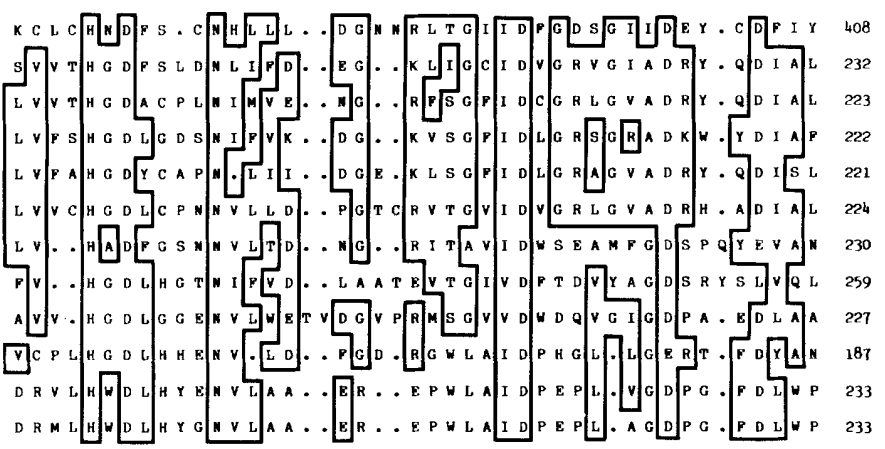

Fig. 5. The conserved region in the predicted amino acid sequences of 15 phosphotransferases. Sequence locations containing more than six conserved or identical amino acids are enclosed in solid lines. Numbers to the right indicate the sequence position of the last amino acid shown. Conserved means replacements within the groups $(I, L, V)(R, K)(D, E)(S, T)(F, Y)(Q, N)$. Gaps have been introduced to maximize homology. Sequence data were taken for the AAC $\left(6^{\prime}\right)$ IV-APH $\left(2^{\prime \prime}\right)$ of Strep. faecalis from Ferretti et al. (1986); for the APH(3')(5")I of Salmonella typhimurium from Oka et al. (1981); for the APH $\left(3^{\prime}\right)\left(5^{\prime \prime}\right)$ II of $K$. pneumoniae from Beck et al. (1982); for the APH( $\left.3^{\prime}\right)\left(5^{\prime \prime}\right)$ IIIs of $S$. aureus, Strep. faecalis and Campylobacter coli from Trieu-Cuot \& Courvalin (1983), Gray \& Fitch (1983) and Trieu-Cuot et al. (1985), respectively; for the Bacillus circulans APH $\left(3^{\prime}\right)\left(5^{\prime \prime}\right)$ IV from Herbert et al. (1983); for the Streptomyces fradiae APH $\left(3^{\prime}\right)\left(5^{\prime \prime}\right) \mathrm{V}$ from Thompson \& Gray (1983); for the APH(4) of $E$. coli from Gritz \& Davies (1983) and Kaster et al. (1983); for the Streptomyces hygroscopicus APH( $\left.7^{\prime \prime}\right)$ from Zalacain et al. (1986); for the Streptomyces vinaceus VPH from Bibb et al. (1985); for the $K$. pneumoniae streptomycin phosphotransferase (SPH) from Mazodier et al. (1985); for the Streptomyces griseus APH(6) from Distler et al. (1987); and for the Streptomyces glaucescens APH(6) from Vögtli \& Hütter (1987).

\section{Polypeptide primary structure homology}

A comparison of the deduced amino acid sequence of the aacA-aphD product with that of other sequenced resistance genes revealed a region of approximately 40 amino acids (368-408) near the C-terminus which is conserved with other APHs and a viomycin phosphotransferase (VPH) (Fig. 5). This suggests that the C-terminal region of the aacA-aphD product is responsible for the $\operatorname{APH}\left(2^{\prime \prime}\right)$ activity and that the conserved residues represent active-site sequences. The conserved asparagine residues (D), being anionic, may be involved in binding of the cationic aminoglycoside substrates. Although there are further sequence positions at which the phosphotransferases show strong homology, these are scattered.

Significant homology was also found between the deduced primary structure of the aacA$a p h D$ product and that of the streptothricin acetyltransferase from Streptomyces lavendulae (Horinouchi et al., 1987), between amino acids 110-153 in the AAC(6') region; no significant homology was found with other sequenced acetyltransferases, which include the AAC(3)III and IV of E. coli (Bräu et al., 1984; Allmansberger et al., 1985) and the chloramphenicol acetyltransferases (CATs) type I and III from E. coli (Shaw et al., 1979; L. Packman, N. Kaye \& S. Fitton, unpublished results, cited in Shaw, 1983) and type C and pC194 from S. aureus (Shaw et al., 1985; Byeon \& Weisblum, 1984). Ferretti et al. (1986) noted homology between the amino acid sequences of the AAC $\left(6^{\prime}\right)-\mathrm{APH}\left(2^{\prime \prime}\right)$ and the CAT from Bacillus pumilus (Harwood et al., 1983); our analysis, however, did not register sequence conservation in this case (amino acid identity was less than $30 \%$ ).

\section{Secondary structure analysis of the aac $A$-aphD product}

Ferretti et al. (1986) attempted to subclone the $\operatorname{APH}\left(2^{\prime \prime}\right)$ domain separately from the Strep. faecalis AAC(6)-APH( $\left(2^{\prime \prime}\right)$, which has an identical predicted sequence to that of the aacA-aphD product, and found that APH activity could only be expressed if most of the $\mathrm{N}$-terminal region, specifying the $\mathrm{AAC}\left(6^{\prime}\right)$ activity, was present in addition to the $\mathrm{C}$-terminal region proposed to specify the $\operatorname{APH}\left(2^{\prime \prime}\right)$ activity; a protein shortened at the $\mathrm{N}$-terminal end by $12 \%$ but not $50 \%$ 
expressed APH activity. Examination of the putative secondary structure of the protein offers an explanation for this; viz., that the $\mathrm{C}$-terminal region takes up a different secondary structure in the whole $\mathrm{AAC}\left(6^{\prime}\right)-\mathrm{APH}\left(2^{\prime \prime}\right)$ protein compared to when it is present in a significantly truncated form (data not shown). Only truncated AAC $\left(6^{\prime}\right)$ - $\mathrm{APH}\left(2^{\prime \prime}\right)$ polypeptides with less than approximately $18 \%$ deleted from the $\mathrm{N}$-terminal end should possess the conformation of the Cterminal domain generated for the wild-type protein, a prediction entirely consistent with the results of Ferretti et al. (1986).

\section{DISCUSSION}

We report here a genetic and biochemical analysis of the resistance to gentamicin, tobramycin and kanamycin encoded by the transposon Tn 4001 from $S$. aureus. Resistance to these aminoglycosides involves AAC and APH modifying enzyme activities, and substrate profiles imply these to be AAC $\left(6^{\prime}\right) \mathrm{IV}$ and $\mathrm{APH}\left(2^{\prime \prime}\right)$ activities, respectively. These activities, which are detected together in staphylococci and streptococci, are specified by a single bifunctional enzyme in the cases of $S$. aureus strains containing plasmids RPAL or pTU053 (Martel et al., 1983; Ubukata et al., 1984), S. epidermidis strain TK1265 (Ubukata et al., 1984) and Strep. faecalis strains harbouring pIP800 (Courvalin et al., 1980; Ferretti et al., 1986). Likewise, the AAC and APH activities encoded by Tn 4001 are also specified by a single enzyme, since expression analysis of the $2.5 \mathrm{~kb}$ HindIII fragment from Tn4001 [which contains the determinant for AAC $\left(6^{\prime}\right)$ and $\mathrm{APH}\left(2^{\prime \prime}\right)$ activities, designated aacA-aphD], and $\mathrm{Tn} 1725$ mutants of it, demonstrated that a single protein with an apparent size of $59 \mathrm{kDa}$ is associated with the activities. This is similar to the sizes reported for purified AAC $\left(6^{\prime}\right)-\mathrm{APH}\left(2^{\prime \prime}\right) \mathrm{s}(54-56 \mathrm{kDa}$; Martel et al., 1983; Ubukata et al., 1984), and is consistent with the nucleotide sequence data, which indicate a polypeptide of $56.9 \mathrm{kDa}$ to be involved.

Additionally, an unidentified reading frame (URF), capable of specifying a $12 \mathrm{kDa}$ protein, occurs $5^{\prime}$ to the $a a c A-a p h D$ coding area. This region does not, however, appear to be involved in the aminoglycoside resistance since the corresponding region in the nearly identical $\mathrm{AAC}\left(6^{\prime}\right)$ APH $\left(2^{\prime \prime}\right)$ determinant from Strep. faecalis plasmid pIP800 (Ferretti et al., 1986) contains a frameshift relative to that of $\mathrm{Tn} 4001$.

There are a number of potential promoter sequences $5^{\prime}$ to the aacA-aphD coding frame. Of these, the two strongest, P1 and P2, lie within the area, bp 197-441, defined by the Tn 1725 insertion and deletion analysis as being important for expression of aminoglycoside resistance. In contrast, Ferretti et al. (1986) suggested that the promoter for the streptococcal AAC $\left(6^{\prime}\right)$ APH $\left(2^{\prime \prime}\right)$ determinant occurs at a position corresponding to bp 623-654 in the $S$. aureus sequence. However, deletions of the aac $A-a p h D$ region starting at the left-hand HindIII site with their end-points occurring $3^{\prime}$ to bp 441 resulted in aminoglycoside resistance being expressed at greatly reduced levels, indicating that the $\mathrm{P} 1 / \mathrm{P} 2$ region is more likely to be the main promoter region for aacA-aphD; conclusive identification of promoter elements awaits transcript analysis. The area between bp 441 and the beginning of the $a a c A$-aphD coding frame, at bp 700, contains P3, which has a slightly lesser fit to the promoter consensus sequence than P1 and P2, and a number of much weaker potential promoters. These promoters may be responsible for the low level of aminoglycoside resistance remaining when the region is deleted or when transcription from $\mathrm{P} 1 / \mathrm{P} 2$ is blocked with a Tn 1725 insertion.

Characterization of $\operatorname{Tn} 1725$ insertions in aacA-aphD indicates that 167-180 codons from the $5^{\prime}$ end of the structural coding region are sufficient to specify the AAC activity, whereas the remaining $3^{\prime}$ portion of the gene presumably encodes the APH activity. These results are consistent with the contention that the AAC and APH activities are specified by separate domains in the aacA-aphD product, and in full support for this Martel et al. (1983) have demonstrated that the AAC and APH active sites of the AAC $\left(6^{\prime}\right)-\mathrm{APH}\left(2^{\prime \prime}\right)$ enzyme encoded by the $S$. aureus plasmid RPAL occur at two separate locations. As such, it has been suggested that the bifunctional enzyme resulted from the fusion of two genes encoding an AAC $\left(6^{\prime}\right)$ and an APH(2") (Martel et al., 1983; Ferretti et al., 1986). If so, then the failure of the APH domain to specify activity when detached from the AAC domain (Ferretti et al., 1986) implies that the APH domain has undergone structural alteration since the fusion event. 
It has been proposed that some resistance mechanisms found in clinical bacterial isolates originated in the antibiotic-producing soil bacteria (Benveniste \& Davies, 1973; Koch, 1981; Gray \& Fitch, 1983). It is, therefore, of interest that AAC $\left(6^{\prime}\right)$ activity with a substrate profile similar to that of the AAC( $\left.6^{\prime}\right) \mathrm{IV}$ of $\mathrm{Tn} 4001$ is found in the kanamycin producer Streptomyces kanamyceticus (Benveniste \& Davies, 1973). However, comparison of the $\mathrm{G}+\mathrm{C}$ contents of Streptomyces and the aacA-aphD region of Tn 4001 , which are $69-73 \%$ and $26 \%$, respectively, indicates that Streptomyces is unlikely to be the immediate origin of the aacA-aphD gene. A possibility, then, is that the direct source of the aacA-aphD gene is a soil organism with a low $\mathrm{G}+\mathrm{C}$ content, such as a Bacillus, that cohabits with an aminoglycoside producer. In contrast to the $a a c A-a p h D$ region, with a $26 \% \mathrm{G}+\mathrm{C}$ content, the sequenced portions of the inverted repeat (IS256) sequences which flank this region on Tn 4001 have a $47 \% \mathrm{G}+\mathrm{C}$ content. This is suggestive of different origins for the IS256 elements and the aacA-aphD determinant of $\operatorname{Tn} 4001$.

Enzymes which confer antibiotic resistance in vivo may have evolved from pre-existing cellular enzymes (Koch, 1981; Samraoui et al., 1986). Known families of nucleotide-binding proteins and phosphotransferases (kinases) were, therefore, examined for sequence homology with the predicted sequence of the AAC $\left(6^{\prime}\right)-\mathrm{APH}\left(2^{\prime \prime}\right)$ and other APH enzymes, but no significant homology was detected, suggesting that the APH $\left(2^{\prime \prime}\right)$ of the bifunctional enzyme and related APHs (Fig. 5) represent a new class of kinases. They may have all evolved from an as yet unidentified cellular kinase.

Comparison of the AAC $\left(6^{\prime}\right)$ sequence with that of a streptothricin acetyltransferase revealed a significant region of homology, which may thus correspond to the binding site for their common co-factor, acetyl-CoA.

The nucleotide sequence of the $a a c A-a p h D$ determinant and flanking regions is almost identical to that of the AAC $\left(6^{\prime}\right)-\mathrm{APH}\left(2^{\prime \prime}\right)$ determinant of Strep. faecalis plasmid pIP800. Since the aacA-aphD determinant is flanked by the IS 256 sequences of Tn 4001 , the result suggests that the Strep. faecalis determinant is also flanked, at least on the side that has been sequenced, by a copy of IS256. That is, a Tn4001-like element also occurs in Streptococcus. This implies the possibility that all cases of $\mathrm{AAC}\left(6^{\prime}\right)-\mathrm{APH}\left(2^{\prime \prime}\right)$ activities, which have been documented only in staphylococci and streptococci, are due to the presence of Tn4001-like elements. Consistent with this notion is the presence of DNA homologous to Tn 4001 in all gentamicin-resistant $S$. aureus strains which we have examined (Lyon et al., 1987a; Gillespie et al., 1987).

Being only $4.7 \mathrm{~kb}$ in size, Tn 4001 is one of the smallest transposons encoding multiple antibiotic resistance, in part due to the bifunctional nature of the single resistance protein that it encodes. Such a transposon appears to be particularly suited for dissemination on nonconjugative plasmids via transduction, with its intrinsic size limitation, as well as on conjugative plasmids. It is not surprising, therefore that Tn4001-like elements have been detected on both types of plasmids, spreading via non-conjugative plasmids in Australian isolates and via both conjugative and non-conjugative plasmids in North American isolates (Lyon et al., 1987a).

We wish to thank Linda Messerotti for skilled technical assistance and Matthew Gillespie for useful discussion. This work was supported by a Project Grant from the National Health and Medical Research Council (Australia).

\section{REFERENCES}

Allmansberger, R., BräU, B. \& Piepersberg, W. (1985). Genes for gentamicin-(3)- $N$-acetyl-transferases III and IV. II. Nucleotide sequences of three AAC(3)-III genes and evolutionary aspects. Molecular and General Genetics 198, 514-520.

Azad, A. A., Barrett, S. A. \& Fahey, K. J. (1985). The characterization and molecular cloning of the dsRNA genome of an Australian strain of Infectious Bursal Disease Virus. Virology 143, 35-44.

Beck, E., Ludwig, G., Auerswald, E., Reiss, B. \& SCHALlER, H. (1982). Nucleotide sequence and exact localization of the neomycin phosphotransferase gene from transposon Tn5. Gene 19, 327-336.

Benveniste, R. \& Davies, J. (1973). Aminoglycoside antibiotic-inactivating enzymes in actinomycetes similar to those present in clinical isolates of antibiotic-resistant bacteria. Proceedings of the National Academy of Sciences of the United States of America 70, 2276-2280.

BibB, M. J., BIBB, M. J., WARD, J. M. \& Cohen, S. N. (1985). Nucleotide sequences encoding and promoting expression of three antibiotic resistance genes 
indigenous to Streptomyces. Molecular and General Genetics 199, 26-36.

BräU, B., Pilz, U. \& Piepersberg, W. (1984). Genes for gentamicin-(3)- $N$-acetyltransferase III and IV. I. Nucleotide sequence of the AAC(3)-IV gene and possible involvement of an IS 140 element in its expression. Molecular and General Genetics 193, 179 187.

BRYAN, L. E. (1984). Aminoglycoside resistance. In Antimicrobial Drug Resistance, pp. 241-277. Edited by L. E. Bryan. New York: Academic Press.

ByeON, W.-H. \& Weisblum, B. (1984). Post-transcriptional regulation of chloramphenicol acetyltransferase. Journal of Bacteriology 158, 543-550.

Casadaban, M. J. \& Cohen, S. N. (1980). Analysis of gene control signals by DNA fusion and cloning in Escherichia coli. Journal of Molecular Biology 138, 179-207.

Chang, A. C. Y. \& Cohen, S. N. (1978). Construction and characterization of amplifiable multicopy DNA cloning vehicles derived from the P15A cryptic miniplasmid. Journal of Bacteriology 134, 1141-1156.

Chen, E. Y. \& Seeburg, P. H. (1985). Supercoil sequencing: a fast and simple method for sequencing plasmid DNA. DNA 4, 165-170.

Courvalin, P., Carlier, C. \& Collatz, E. (1980). Plasmid-mediated resistance to aminocyclitol antibiotics in group D streptococci. Journal of Bacteriology 143, 541-551.

Cram, H. K., Cram, D. \& Skurray, R. (1984). F plasmid pif region: $\mathrm{Tn} 1725$ mutagenesis and polypeptide analysis. Gene 32, 251-254.

Distler, J., Braun, C., Ebert, A. \& Piepersberg, W. (1987). Gene cluster for streptomycin biosynthesis in Streptomyces griseus: analysis of a central region including the major resistance gene. Molecular and General Genetics 208, 204-210.

Ferretti, J. J., Gilmore, K. S. \& Courvalin, P. (1986). Nucleotide sequence analysis of the gene specifying the bifunctional $6^{\prime}$-aminoglycoside acetyltransferase 2 "-aminoglycoside phosphotransferase enzyme in Streptococcus faecalis and identification and cloning of gene regions specifying the two activities. Journal of Bacteriology 167, 631-638.

FosTER, T. J. (1983). Plasmid-determined resistance to antimicrobial drugs and toxic metal ions in bacteria. Microbiological Reviews 47, 361-409.

Garnier, J., OSGUTHORPE, D. J. \& RobSON, B. (1978). Analysis of the accuracy and implications of simple methods for predicting the secondary structure of globular proteins. Journal of Molecular Biology 120 , 97-120.

Gillespie, M. T., Lyon, B. R., Messerotti, L. J. \& Skurray, R. A. (1987). Chromosome- and plasmidmediated gentamicin resistance in Staphylococcus aureus encoded by Tn4001. Journal of Medical Microbiology 24, 139-144.

GraY, G. S. \& Fitch, W. M. (1983). Evolution of antibiotic resistance genes: the DNA sequence of a kanamycin resistance gene from Staphylococcus aureus. Molecular Biology and Evolution 1, 57-66.

Gritz, L. \& DAVIES, J. (1983). Plasmid-encoded hygromycin B resistance: the sequence of hygromycin B phosphotransferase gene and its expression in Escherichia coli and Saccharomyces cerevisiae. Gene 25, 179-188.
Harwood, C. R., Williams, D. M. \& Lovett, P. S. (1983). Nucleotide sequence of a Bacillus pumilus gene specifying chloramphenicol acetyltransferase. Gene 24, 163-169.

Herbert, C. J., Giles, I. G. \& Akhtar, M. (1983). The sequence of an antibiotic resistance gene from an antibiotic-producing bacterium. FEBS Letters 160 , 67-71.

Horinouchi, S., Furuya, K., Nishiyama, M., SuzUKi, H. \& BEPPU, T. (1987). Nucleotide sequence of the streptothricin acetyltransferase gene from Streptomyces lavendulae and its expression in heterologous hosts. Journal of Bacteriology 169, 1929-1937.

KASTER, K. R., Burgett, S. G., RAO, R. N. \& INGOLIA, T. D. (1983). Analysis of a bacterial hygromycin B resistance gene by transcriptional and translational fusions and by DNA sequencing. Nucleic Acids Research 11, 6895-6911.

KoCH, A. L. (1981). Evolution of antibiotic resistance gene function. Microbiological Reviews 45, 355-378.

le Goffic, F., Martel, A., Moreau, N., Capmau, M. L., Soussy, C. J. \& Duval, J. (1977). 2"-Ophosphorylation of gentamicin components by a Staphylococcus aureus strain carrying a plasmid. Antimicrobial Agents and Chemotherapy 12, 26-30.

LyoN, B. R. \& SKurRay, R. (1987). Antimicrobial resistance of Staphylococcus aureus: genetic basis. Microbiological Reviews 51, 88-134.

Lyon, B. R., May, J. W. \& Skurray, R. A. (1984). Tn4001: a gentamicin and kanamycin resistance transposon in Staphylococcus aureus. Molecular and General Genetics 193, 554-556.

Lyon, B. R., Gillespie, M. T., Byrne, M. E., May, J. W. \& SkURray, R. A. (1987a). Plasmid-mediated resistance to gentamicin in Staphylococcus aureus: the involvement of a transposon. Journal of Medical Microbiology 23, 105-114.

Lyon, B. R., Gillespie, M. T. \& Skurray, R. A. $(1987 b)$. Detection and characterization of IS 256 , an insertion sequence in Staphylococcus aureus. Journal of General Microbiology 133, 3031-3038.

Martel, A., Masson, M., Moreau, N. \& Le Goffic, F. (1983). Kinetic studies of aminoglycoside acetyltransferase and phosphotransferase from Staphylococcus aureus RPAL. Relationships between the two activities. European Journal of Biochemistry 133, 515521 .

Mazodier, P., Cossár, P., Giraud, E. \& Gasser, F. (1985). Completion of the nucleotide sequence of the central region of $\operatorname{Tn} 5$ confirms the presence of three resistance genes. Nucleic Acids Research 13, 195-205.

McDonnell, R. W., Sweeney, H. M. \& Cohen, S. (1983). Conjugational transfer of gentamicin resistance plasmids intra- and interspecifically in Staphylococcus aureus and Staphylococcus epidermidis. Antimicrobial Agents and Chemotherapy 23, 151-160.

Mclaughlin, J. R., Murray, C. L. \& Rabinowitz, J. C. (1981). Unique feature in the ribosome binding site sequence of the Gram-positive Staphylococcus aureus $\beta$-lactamase gene. Journal of Biological Chemistry 256, 11283-11291.

MEssing, J. (1983). New M13 vectors for cloning. Methods in Enzymology 101, 10-89.

Messing, J. \& Vieira, J. (1982). A new pair of M13 vectors for selecting either DNA strand of doubledigest restriction fragments. Gene 19, 269-276. 
Moran, C. P., Jr, Lang, N., Legrice, S. F. J., Lee, G., Stephens, M., Sonenshein, A. L., Pero, J. \& Losick, R. (1982). Nucleotide sequences that signal the initiation of transcription and translation in Bacillus subtilis. Molecular and General Genetics 186, 339-346.

Novick, R. P., Iordenescu, S., Surdeanu, M. \& EDElman, I. (1981). Transduction-related cointegrate formation between staphylococcal plasmids: a new type of site-specific recombination. Plasmid 6, 159-172.

OKa, A., Sugisaki, H. \& Tanakami, M. (1981). Nucleotide sequence of the kanamycin resistance transposon Tn903. Journal of Molecular Biology 147, 217-236.

Phillips, I. \& Shannon, K. (1984). Aminoglycoside resistance. British Medical Bulletin 40, 28-35.

Ray, A. \& Skurray, R. (1983). Cloning and polypeptide analysis of the leading region in F plasmid DNA transfer. Plasmid 9, 262-272.

ROSENBERG, M. \& COURT, D. (1979). Regulatory sequences involved in the promotion and termination of transcription. Annual Review of Genetics 13, 319-353.

Sadaie, Y., Burtis, K. C. \& DoI, R. H. (1980). Purification and characterization of a kanamycin nucleotidyltransferase from plasmid pUB110-carrying cells of Bacillus subtilis. Journal of Bacteriology 141, 1178-1182.

Samraoui, B., Sutton, B. J., Todd, R. J., Artymiuk, P. J., Waley, S. G. \& Phillips, D. C. (1986). Tertiary structural similarity between a class A $\beta$ lactamase and a penicillin-sensitive $D$-alanyl carboxypeptidase-transpeptidase. Nature, London 320 , 378-381.

SANCAR, A., HaCK, A. M. \& RupP, W. D. (1979). A simple method for identification of plasmid-coded proteins. Journal of Bacteriology 137, 692-693.

Sanger, F., Nicklen, S. \& Coulson, A. R. (1977). DNA sequencing with chain-terminating inhibitors. Proceedings of the National Academy of Sciences of the United States of America 74, 5463-5467.

Schoffl, F., ARnold, W., Puhler, A., AltenBUCHER, J. \& SCHMITT, R. (1981). The tetracycline resistance transposons $\operatorname{Tn} 1721$ and $\operatorname{Tn} 1771$ have three 38-base-pair repeats and generate five-basepair direct repeats. Molecular and General Genetics 181, 87-94:

Shannon, K. P. \& Phillips, I. (1983). Detection of aminoglycoside-modifying strains of bacteria. In Antibiotics (Society for Applied Bacteriology Technical Series no. 18), pp. 183-198. Edited by A. D. Russell \& L. B. Quesnel. London: Academic Press.

SHAw, W. V. (1983). Chloramphenicol acetyltransfer- ase: enzymology and molecular biology. CRC Critical Reviews in Biochemistry 14, 1-46.

Shaw, W. V., Packman, L. C., Burleigh, B. D., Dell, A., Morris, H. R. \& Hartley, B. S. (1979). Primary structure of a chloramphenicol acetyltransferase specified by R plasmids. Nature, London 282 , 870-874.

Shaw, W. V., Brenner, D. G., Legrice, S. F. J., Skinner, S. E. \& Hawkins, A. R. (1985). Chloramphenicol acetyltransferase gene of staphylococcal plasmid pC221. FEBS Letters 179, 101-106.

STADEN, R. (1986). The current status and protability of our sequence handling software. Nucleic Acids Research 14, 217-231.

Thompson, C. J. \& Gray, G. S. (1983). Nucleotide sequence of a streptomycete aminoglycoside phosphotransferase gene and its relationship to phosphotransferases encoded by resistance plasmids. Proceedings of the National Academy of Sciences of the United States of America 80, 5190-5194.

Trieu-Cuot, P. \& Courvalin, P. (1983). Nucleotide sequence of the plasmid gene encoding the aminoglycoside phosphotransferase $\mathrm{APH}\left(3^{\prime}\right)\left(5^{\prime \prime}\right) \mathrm{III}$ in Streptococcus faecalis. Gene 23, 331-341.

Trieu-Cuot, P., Gerbaud, G., Lambert, T. \& Courvalin, P. (1985). In vivo transfer of genetic information between Gram-positive and Gramnegative bacteria. EMBO Journal 4, 3583-3587.

UbBen, D. \& Schmitt, R. (1986). Tn 1721 derivatives for transposon mutagenesis. Gene 41, 145-152.

Ubukata, K., Yamashita, N., Gotoh, A. \& Konno, M. (1984). Purification and characterization of aminoglycoside-modifying enzymes from Staphylococcus aureus and Staphylococcus epidermidis. Antimicrobial Agents and Chemotherapy 25, 754-759.

VöGTLI, M. \& HüTTER, R. (1987). Characterization of the hydroxystreptomycin phosphotransferase gene $(s p h)$ of Streptomyces glaucescens: nucleotide sequencing and promoter analysis. Molecular and General Genetics 208, 195-203.

West, R. W., JR. \& Rodriguez, R. L. (1982). Construction and characterization of Escherichia coli promoter-probe vectors. III. pBR322 derivatives with deletions in the tetracycline resistance promoter region. Gene 20, 291--304.

YANisch-Perron, C., Vieira, J. \& Messing, J. (1985). Improved M13 phage cloning vectors and host strains: nucleotide sequences of the M13 mp18 and pUC19 vectors. Gene 33, 103-119.

Zalacain, M., Gonzales, A., Guerrero, M. C., Mataliano, F., Malpartida, F. \& Jiminez, A. (1986). Nucleotide sequence of the hygromycin B phosphotransferase gene from Streptomyces hygroscopicus. Nucleic Acids Research 14, 1565-1581. 